\title{
Constructs and Relationships of Edutainment Applications in Marketing Classes: How Edutainment Can be Utilized to Act as a Magnet for Choosing a Course?
}

\author{
Metin Argan \\ Necip Serdar Sever \\ Anadolu University, Turkey
}

\begin{abstract}
The purpose of this study was to investigate the constructs of edutainment applications and their relationships during marketing communication courses. A sample of 347 undergraduate students completed a 27-item questionnaire to gather research data. The confirmatory factor analysis revealed five valid constructs: Participation and interaction, perceived learning effects, drama and practice, instructor and classroom atmosphere, and story and material. These constructs were further analyzed by the structural equation modeling (SEM), which indicated that four of the constructs were found to be effective on the perception of learning. Instructor and classroom atmosphere was revealed to have a direct (mediating) impact on perceived learning, whereas other constructs had an indirect effect on perceived learning. It appears that the research findings would help tertiary institutions to develop more learnercentered approaches to learning, and will certainly help marketing individual courses at the micro level.
\end{abstract}

Keywords: Edutainment; Entertainment; Marketing Communication Education; Experiential Learning.

\section{Introduction}

Just as in business and service sectors, field of education is not immune to consumer centered restructuring of its infrastructure. Pelton and True (2004) suggest that if we aim to teach something to next generations, then we should think about aligning of teaching methods with their needs and wants. Entertainment seems to fill its long overdue seat in education too. When making course choice, students consider level of fun (i.e., audio and visual materials) that they expect from their choice (Uslay, 2007). Therefore, instructors should design their courses in a way that it would satisfy such expectations.

The factors such as students' level of talents, experiences, commitments, and environment surrounds them have long been popular study contents. Nevertheless, bridging these subjects with delivery systems should be brought to attention of researchers both in marketing and education disciplines. In fact, delivery methods, instructor attributes, teaching materials, etc. are all effective motivators on students in order to get them involved during in-class discussions. 
Nevertheless studies that investigate the possible outcomes of using edutainment in lectures from students' perspectives are rather limited. Academics in marketing field are opting for the effects of experiential teaching methods on students in greater numbers (Bobbitt et al., 2000; Klink and Athaide, 2004).

The best possible way to characterize the edutainment is to describe the concept as adopting entertaining ways and components, and utilizing them in lectures. Today edutainment has a broader meaning. It is not just game playing. Apparently, various disciplines are now adopting edutainment for enhancing the teaching and learning environments. This study examines how marketing students at university level perceive the use of edutainment in their courses. The researchers however, by no means attempted to measure how much amount of edutainment is effective on teaching and learning levels of students.

\section{Literature Review and Research Hypotheses}

Since 1970's edutainment applications built upon various learning theories have been in use for the development of educational games (Egenfeldt-Nielsen, 2007). Currently, a worldwide bridging of technical developments and traditional sources of entertainment with educational tools has been taking place (Bird, 2005). Nowadays, edutainment is far from being an educational computer game. It is reaching to a wider perspective in terms of its content and applications. "Edutainment", is a hybrid concept that skews heavily on visual material, on narrative or game-like formats, and on rather informal, less didactic styles of presentation. It is an umbrella term that is a blend of a content in a form of education and entertainment so as to use the content on a variety of media platforms including computer games (Buckingham and Scanlon, 2002; Egenfeldt-Nielsen, 2007). Green and McNeese, (2007) indicate that "the main purpose of edutainment is to promote student learning through exploration, interactivity, trial and error, and repetition in such a way that students get so lost in the fun, that they don't realize they are learning at same time." In other words, one of the main aims of edutainment is to draw learners' attention and keep it consistently focused on events and teaching materials during the learning process (Okan, 2003). For this reason, edutainment applications should embrace various methods, including computer technologies.

The message contribution (the entertainment and education content) and the consumer's contribution (individual subjective responses) together give rise to the person's edutainment experience (Addis, 2005). Edutainment practices can be grouped under four categories. These categories are participation and interaction, drama and practices, story and material, and instructor and classroom atmosphere. Hereafter, these four categories will be detailed in order to set up a concrete basis for the hypotheses tested in the study.

\section{Participation and Interaction}

From theoretical point, consumption is the experience derived from the interaction between a subject (consumer or student), and an object (a product, an event, an idea, a person, a course etc.) within a given context (Addis, 2005). Several studies pointed to the "immersive experience and 
concluded that consumers' reactions to such experiences as participation to interaction from edutainment perspective (Addis, 2005; Kinney 1995). Just as in games, in education sector students should be considered as 'consumers' and their involvement to course contents and materials can be increased through embedding fun as a component to lectures. Clarke (2008) indicates that experiential learning activities can only be achieved if students can involve in such activities, and plays a pivotal role in this sequence. Experiential learning methods, tied up with learning objectives can altogether reveal fun and useful experiences (Wooldridge, 2006). Evidently, experience-based learning improves student learning spectrum more as compare to traditional learning methods.

From student satisfaction point, every course has two vital elements. These are students and their evaluations regarding course. Based on traditional marketing paradigm, every course is a service and every service requires an encounter with service provider. In this case, the service provider would be an instructor. Customers/students evaluate a course based on the impression they get and the experience that they lived in their encounter with service provider/instructor (Solomon et al., 1985). Instructor's efforts to get students involve to in-class discussions will ultimately affect the learning outcomes. From this perspective, learning outcome has been directly related to supportive-type class behaviors such as class attendance (Young et al., 2003). Even one student can play a role over others' learning experiences (Curran and Rosen, 2006). In addition, Dallimore et al. (2006) claimed that classroom discussion or participation is frequently posited as an "active learning" strategy to engage students in the class. According to Nunn (1996), class participation at the university level is valued, as there is a positive relationship between participation and active learning (Wooldridge, 2008).

Several studies revealed that interaction with the instructor and with classmates, and active participation to in-class activities affect student satisfaction level (Appleton-Knapp and Krentler, 2006). Curran and Rosen (2006) found seven factors that students use to evaluate a course. Among them peer factor, learning environment, teaching format and the instructor's characteristic are some that emphasize the importance of interaction in teaching and learning. Based on these implications, it is assumed that interaction is interrelated to level of drama and practices, stories, and teaching material used during the lectures. Based upon argumentation above, following hypotheses were developed:

H1: Participation and interactivity are positively related with the use of drama and practices in the marketing related courses.

H2: Participation and interactivity are positively related with the stories and teaching materials used in the marketing related courses.

\section{Drama and Practices}

According to Pearce (2006), educational drama is defined as conventional use of role-play. Drama as pedagogy is founded on the notion of experiential learning. Active and experiential learning methods are widely used in many areas of tertiary teaching (Sojka and Fish, 2008). Such methods commonly employ role-playing and more hands on learning techniques. In doing so, students are 
drawn into the learning process and have fun at the same time (Frontczak and Kelley, 2000). For instance, personal sales games teach students various sales techniques and help them to practice their skills among peers (Moncrief, 1991; Sojka and Fish, 2008; Tanner and Chonko, 1992). Similarly, distribution systems can be best explained with role-playing in beginning marketing courses (Schee, 2007). All such activities are considered as entertaining because of the fact that they have an entertaining nature (Sojka and Fish, 2008).

Games can be in various forms such as question and answer, simulations and contests. In Pearce (2006) study, enjoyment merged as a cluster; it makes students curiously wait for the next lecture. Students view games as fun and a casual atmosphere where students are comfortably laughing and smiling (Schee, 2007). Games have a positive impact on learning but this effect can only exist with the mediation of instructor and classroom atmosphere factors. Based upon these theoretical assumptions, researchers developed the following hypothesis.

H3: Drama and practices are positively related with instructor and classroom atmosphere.

\section{Story and Material}

Evidently, teaching materials have substantial effects on learning outcomes. Teaching materials that are used in creative ways would increase student participation. Of course, this is also true for marketing courses. Despite the fact that studies on learning environment and their possible effects on learning are numerous, studies on teaching materials are rather relatively limited (Young et al., 2003).

However, these limited studies indicate that use of technology in marketing education is common and even in rise. Furthermore, these studies indicate that the use of technology affects student participation (Allred and Swenson, 2006). Case studies and anecdotal events have been widely used in marketing education (Uslay, 2007). Students can actively involve to discussions and even associate themselves with real life events and stories used in lectures. More recently in the marketing education literature, a positive relationship was found between self-reported overall learning and the use of some educational tools (Clarke et al., 2001; Young et al., 2003). Based upon these findings, the following hypothesis was developed:

H4: Stories and materials are positively related with instructor and classroom atmosphere.

\section{Instructor and Classroom Atmosphere}

Obviously, instructors play an important role in delivery of university-level courses (Curran and Rosen, 2006; Stapleton and Murkison, 2001) and help students comprehend as well as perceive the subject.

Majority of studies have focused on the multidimensional nature of student evaluations of class experiences, and particularly, the instructor. Instructor is undoubtedly an important ingredient in the success or failure of a given course; nevertheless, it is equally important to understand other 
factors that may be influential to student evaluations of the course and the instructor (Curran and Rosen, 2006).

The physical and psychological atmosphere that is created by the instructor can be considered as components of service marketing (Bitner, 1992). Instructor characteristics, teaching materials, instructional methods, and learning atmosphere are all effective on perceived course satisfaction by students (Dana et al., 2001). On these grounds, in order to examine the degree of relationship between the constructs of instructor and classroom atmosphere and their effect on perceived learning, the following hypothesis was developed:

H5: Instructor and atmosphere are positively related with learning effects in marketing related courses.

Finally, in order to explain research constructs, the following conceptual model is developed. The result of the structural equation model derived from LISREL analysis will be benchmarked against to the conceptual model. Figure 1 displays constructs and their relationships used in marketing courses under the auspice of this research.

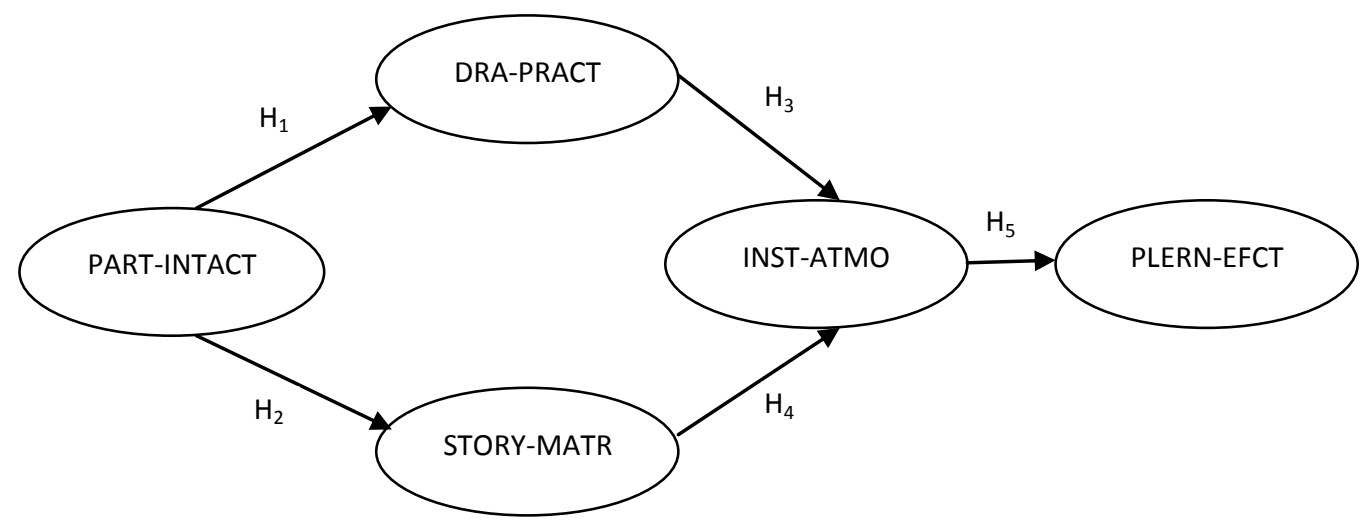

Figure 1. The Conceptual Model

\section{Method}

\section{Sample}

The sample of the study consisted of 347 undergraduate students from the Faculty of Economics and Administrative Sciences, the Faculty of Communication Sciences, and the School of Physical Education and Sports at Anadolu University, Turkey. These schools caters majority of marketing related courses and thus were chosen as a population. Approximately $54 \%$ of the participants were male and $46 \%$ were female. As far as the age groups of the participants are concerned, the ratio of participants at 20 and 21 age bracket was $42 \%$, followed by respondents at 22 and 23 age bracket with $38 \%$. 
The distributions of respondents by academic programs were as follows: $76 \%$ of respondents were from the Faculty of Economics and Administrative Sciences, $16 \%$ of the respondents were from the School of Physical Education and Sports, and $8 \%$ of the respondents were from the Faculty of Communication Sciences. The distributions of respondents by their current year of study were as follows: Seniors constituted the largest student cohort by $43 \%$, followed by the sophomores with $26 \%$, and the juniors with $23 \%$. The distribution of the respondents to the courses that were subject to this study were e-Marketing by $34 \%$, Marketing Principles by $31 \%$, Introduction to Advertising by $11 \%$, Sports Marketing by $10 \%$, Marketing Communications by $8 \%$, and finally Service Marketing by $6 \%$.

\section{Data Gathering Instruments}

Since studies on edutainment applications in marketing courses are quite limited and new, the researchers developed an original scale for the study. In order to generate items that consisted of the domain of attitudes about potential edutainment applications related to marketing courses, three focus-group interviews were conducted with a judgmental sample (34 people) in The School of Physical Education and Sports at Anadolu University, Turkey. In constructing the focus-groups, respondents were selected on the basis of being representative of the population for marketing courses. In these focus-groups, participants were asked to talk about their attitudes about edutainment samples related to the courses, in regard to their experiences and feelings toward educational applications in marketing courses. Then, moderator generated a total of 35 items.

Two marketing communication specialists and the moderator agreed that 8 of the 35 items were either overlapping with each other or were not directly related to the target constructs of the study. Finally, the 35 items were reduced to 27 items. Based on the results of these consultation and elimination process, the items were revised and the preliminary questionnaire was developed. The questionnaire was further pre-tested on a group of 36 students which were considered to be representative of the target population. This pilot-testing reduced redundancy and improved wording of the questionnaire.

The final version of the questionnaire consisted of two parts. The first part was comprised of 27 statements related to attitudes towards edutainment. The statements used in this part were adapted and inspired from three focus-group implementations. A total of 27 statements were thus presented and respondents were asked to indicate their attitudes to each of the statements on a five-point Likert scale. The possible responses ranged from " 5 = strongly agree" to " $1=$ strongly disagree". Reliability coefficients for the sub-categories ranged from .73 to .88 (see Table 2). The second part of the questionnaire included demographic and academic information about students.

\section{Procedures}

In order to gather data from the participants, a self-administrated questionnaire was handed by the four trained researchers. Questionnaires were filled out by respondents at the researchers' presence in the room. The main venues of the research were classrooms and lecture halls of the respective schools. The researchers first briefly explained the purpose of the study to participants, 
and then proceeded to handing in questionnaires to students who agreed to participate in the research voluntarily. The preliminary briefing of participants and filling the questionnaires lasted approximately 15 minutes. A total of 400 questionnaires were distributed but 347 of them were completed by the respondents, which corresponds to return rate of $87 \%$.

\section{Findings and Results}

\section{Assessment of Constructs}

In order to analyze the data and to assess the validity of the scale, an exploratory factor analysis (EFA) was applied. Exploratory factor analysis often cited as a useful preliminary technique for scale-construction and used to purify items in the study (Gerbing and Anderson, 1988; Ozer, Kocak and Celik, 2006). Based on the results of exploratory factor analysis, four items were omitted from the study due to low factor loadings and because some items were found to be deployed in more than one construct. Following the omission of these four items, exploratory factor analysis was applied for the second time. In order to apply factor analysis on items underlying the attitudes of students towards edutainment applications in marketing courses, it was necessary to test the Kaiser-Meyer Olkin (KMO) measure of sampling adequacy (Zhang et al., 2003). For the attitude variables, Kaiser-Meyer Olkin (KMO) was 0.902, indicating that the sample was adequate for factor analysis (Kaiser, 1974). The Bartlett Test for Sphericity (BTS) was 3176.534 ( $p<.001$ ), indicating that the hypothesis variance and covariance matrix of variables as an identity matrix were rejected; therefore, factor analysis was appropriate.

Table 1. Constructs and Items of Edutainment Applications

\begin{tabular}{|c|c|c|c|c|c|}
\hline Constructs & $\begin{array}{l}\text { Stand. } \\
\text { Loadings }\end{array}$ & Mean & $S D$ & $\begin{array}{c}t- \\
\text { Values }\end{array}$ & $\begin{array}{l}\text { Construct } \\
\text { Reliability }\end{array}$ \\
\hline Participation and interaction (PART-INTACT) & .57 & 4.00 & 0.89 & 8.20 & .84 \\
\hline $\begin{array}{l}\text { Exchange of views at the last quarter of an hour of a } \\
\text { lecture affects my learning }\end{array}$ & .79 & 3.87 & 0.99 & 12.49 & \\
\hline Participating students to lecture helps learning & .57 & 3.97 & 0.87 & 8.28 & \\
\hline $\begin{array}{l}\text { Classrooms organized in a way to boost the participation } \\
\text { helps focusing my attention to lectures }\end{array}$ & .74 & 3.98 & 0.94 & 11.43 & \\
\hline $\begin{array}{l}\text { Lectures where students can exchange opinions are more } \\
\text { enjoyable than others }\end{array}$ & $\begin{array}{l}.67 \\
.74\end{array}$ & $\begin{array}{l}3.70 \\
3.61\end{array}$ & $\begin{array}{l}0.89 \\
1.09\end{array}$ & $\begin{array}{l}10.00 \\
11.47\end{array}$ & \\
\hline $\begin{array}{l}\text { Student participation is a must for an enjoyable lecture } \\
\text { Instructor's efforts to get me participate to lectures, } \\
\text { increases my attention level }\end{array}$ & & & & & \\
\hline Perceived Learning effects (PLERN-EFCT) & .83 & 4.34 & 0.71 & 13.85 & .88 \\
\hline $\begin{array}{l}\text { Subjects delivered in an entertaining way are more easier } \\
\text { to remember Entertaining lectures helps me to } \\
\text { comprehend the subject }\end{array}$ & $\begin{array}{l}.81 \\
.86\end{array}$ & $\begin{array}{l}4.40 \\
4.38\end{array}$ & $\begin{array}{l}0.70 \\
0.70\end{array}$ & $\begin{array}{l}13.46 \\
14.82\end{array}$ & \\
\hline
\end{tabular}


The subject that I learned in lectures with entertaining elements becomes permanent

I am more successful in the exam of subjects in which its lectures were entertaining

Drama and practice (DRA-PRACT)

Instructor effort to make students participate the lectures in a theatrical style helps my understanding of a subject

Having lectures in locations which is appropriate to subject makes my learning permanent

Encouraging and entertaining rewards helps my learning

Games that matches with the subject help my learning

Improvisation games helps my learning

Instructor and classroom atmosphere (INST-ATMO)

As long as well-balanced, entertainment does not negatively effect the seriousness of learning

Having and enjoyable lecture is up to in-class atmosphere

Having an enjoyable lecture is up to lecturer

If Instructor has an enjoyable style this draw my attention to lecture

Story and material (STORY-MATR)

If enriched with real-life examples such lecture increase my attentions

Visual material draw my attention to lectures

Case study discussions makes subject more easy to understand

If not boring, use of movies and photographs focuses my attention to subject

As long as related to subject fictions or real-life stories are attention gatherers

$\begin{array}{cccc}.52 & 4.02 & 1.01 & 7.28 \\ .49 & 4.06 & 0.92 & 5.82 \\ & & & \\ .62 & 3.79 & 1.14 & 9.05 \\ .78 & 3.50 & 1.15 & 12.05 \\ .81 & 3.72 & 1.08 & 12.68\end{array}$

.77

.73

$\begin{array}{llll}.49 & 4.49 & 0.69 & 5.52 \\ & & & \\ .45 & 4.28 & 0.83 & 5.09 \\ .54 & 4.39 & 0.69 & 7.51 \\ .79 & 4.44 & 0.67 & 11.68\end{array}$

.75 $\begin{array}{lll}4.72 & 0.58 \quad 8.12\end{array}$

$\begin{array}{lll}4.31 & 0.77 \quad 5.82\end{array}$

$\begin{array}{lll}4.54 & 0.66 & 9.53\end{array}$

$\begin{array}{lll}4.44 & 0.71 \quad 8.90\end{array}$

$\begin{array}{llll}.70 & 4.48 & 0.69 & 10.11\end{array}$

S.D. Standard Deviation; $1=$ Strongly Disagree 5= Strongly Agree.

Fit statistics: $X^{2}(242)=365.89, p<0.001, C F I=0.94, I F I=0.94, N N F I=0.93$, RMSEA $=0.051$, $\mathrm{SRMR}=0.073, \mathrm{GFI}=0.87, \mathrm{AGFI}=0.83$

According to principal axis analysis, five factors had an eigen value equal to or greater than 1.0 (Kaiser, 1960), explaining a total of 58.48 percent of the variance. These factors were termed: "participation and interaction", "perceived learning effects", "drama and practice", "instructor and classroom atmosphere", and "story and material". The participation and interaction factor contained six items, relating to the participation and interaction levels of students in marketing 
courses. The second factor, labeled as learning effects, contained four items, all-relating to the success dimensions of edutainment applications. Factor analysis displayed high loadings for the items. The third factor, labeled as drama and practice, consisted of five items, related to games and dramas in marketing courses. The fourth factor, labeled as instructor and classroom atmosphere, consisted of four items, relating to the role of instructor and situation of classroom atmosphere. Lastly, the fifth factor, labeled as story and material, contained five items about interactive and entertainment teaching materials, and story or cases from real life in marketing world. All five constructs met the criterion that a factor loading should be equal to or greater than 0.45 .

Correlation coefficients among the constructs are displayed in Table 2. The bi-variate relationships revealed that all of the variables significantly correlated (ranged between 0.282 and 0.591 ). Constructs-based scales were generated by summating the relevant items. By running descriptive statistics on data, means and standard deviations were found for each factor. According to descriptive statistics, the construct of story and material had higher score (mean 4.50) as compare to constructs.

Table 2. Correlation Matrix and Descriptive Statistics

\begin{tabular}{lccccc}
\hline Constructs & 1 & 2 & 3 & 4 & 5 \\
\hline PART-INTACT & 1.000 & & & & \\
PLERN-EFCT & $.351^{* *}$ & 1.000 & & & \\
DRA-PRACT & $.476^{* *}$ & $.457^{* *}$ & 1.000 & & \\
INST-ATMO & $.282^{* *}$ & $.591^{* *}$ & $.356^{* *}$ & 1.000 & \\
STORY-MATR & $.351^{* *}$ & $.481^{* *}$ & $.367^{* *}$ & $.496^{* *}$ & 1.000 \\
\hline Mean & 3.86 & 4.33 & 3.82 & 4.40 & 4.50 \\
(S.D.) & $(0.70)$ & $(0.63)$ & $(0.77)$ & $(0.51)$ & $(0.48)$ \\
\hline$* p<0.05 ;{ }^{* *} \mathrm{p}<0.01 ;$ & (S.D.): Standard Deviation \\
\hline
\end{tabular}

Based on exploratory factor analysis results (EFA), 24 items of edutainment applications were then subjected to a confirmatory factor analysis (CFA), using LISREL 8.51 (Jöreskog and Sörbom, 1998). The measurement model of edutainment applications was found to fit the data adequately, although the Chi-square goodness-of-fit index was statistically significant $(365.89, p<0.01)$. It is commonly accepted that Chi-square statistic will reject valid models in large samples (Baggozi and Yi, 1988; Bove and Johnson, 2006); therefore, many researchers relied on the goodness-of-fit (GFI), the comparative fit index (CFI), the incremental fit index (IFI), the non-normed fit index (NNFI), the standardized root mean square residual (SRMR), and the root mean square error of approximation (RMSEA) (e.g., Chin, 1998; Longo and Mura, 2007; Meehl, 1990; Ozer, Kocak and Celik, 2006).

Table 1 presents the values of fit statistics. CFI and NNFI demonstrate how much better the hypothesized model fits compared to the base model. Any value greater than $0.90 \mathrm{in} \mathrm{CFI} \mathrm{and} \mathrm{NNFI}$ indexes indicates an acceptable fit with the data ( $\mathrm{Hu}$ and Bentler, 1999). SRMR and RMSEA measure the poorness of fit (Lee, Graefe and Burns, 2007). Browne and Cudeck (1993) suggested 
that SRMR and RMSEA should be below the cut-off value 0.08. In the measurement model, the RMSEA value of 0.051 was well below 0.1 or 0.08 , indicating a low discrepancy between the implied covariance in the model and observed covariance in the data (Li, Liu and Zhao, 2006). In addition, the SRMR value (0.073) was also below the 0.08 .

Three of all four incremental fit indices (GFI=0.87, CFI=0.94, NNFI=0.93, IFI=0.94) met or exceeded the preferred level of 0.9 (Gefen, Straub, \& Boudreau, 2000; Soto-Acosta and o-Cerdan, 2008). Only GFI was less than the required level and close to it at 0.87 . Moreover, the adjusted goodness of index (GFI) was 0.87 , which is slightly low but still acceptable (Bagozzi and Yi, 1988).

Despite the fact that reliability is important to measure, it is not sufficient for developing the scale all by itself. Confirmatory factor analysis would be required to evaluate, refine and result the scales (Gerbing and Anderson, 1988; Ozer, Kocak and Celik, 2006). In this respect, in addition to reliability, validity scores of confirmatory factor analysis become vital.

One of the most critical elements in generating the content validity of the items in a survey is conceptually defining the domain of the characteristics (Churchill, 1995). Content validity of the study was established through the adoption of validated instruments by previous studies (Cowton, 1998). After the initial scale is prepared, as Churchill (1979) suggested, one specialist who was informed about the purpose of the study was asked to refine the scale and adjust the items about edutainment applications.

Bagozzi and Yi (1988) defined a factor loading exceeding 0.70 as evidence of convergent validity. As suggested by Meehl (1990) and Chin (1998) most of the loadings should be, in CFA models, 0.60 or above, indicating that each measure is accounting for a consistent portion of the variance of the underlying latent variable (Longo and Mura, 2007). Child (1970) states that a factor loading value of 0.50 and above is considered good and very significant, whereas 0.45 is fair and 0.32 and below is poor. As shown in Table 1, factor loadings indicate acceptable item convergence on the intended constructs.

Construct validity is the extent to which the items on a scale measure the abstract or theoretical construct (Churchill, 1979). As also reported in Table 1, overall scale and five reliability coefficients exceeded the 0.70 cut-off value as recommended by Nunnally (1978).

Discriminant validity is the degree to which measures of different constructs are unique enough to be distinguished from other constructs ( $\mathrm{Li}$ et al., 2006). As shown in Table 2, correlation between factors ranged from 0.282 to 0.591 , with the correlations of no pair of measures exceeding the criterion level of 0.90 and above (Hair et al., 1998).

Typically, reliability coefficients of 0.70 or higher are considered adequate (Kim et al., 2003; Nunnally 1978). For all 24 items, the alpha was 0.90. As can be seen from Table 1, Cronbach's alpha values of five factors were above 0.70 , indicating a satisfactory level of internal consistency among items in each construct. In conclusion, the many of fit statistics, validity, and reliability measures allow the confirmation of the proposed model. 


\section{Structural Model Evaluation}

The conceptual model and the hypotheses of edutainment implications in marketing courses were tested using structural equation modeling. Figure 2 shows the model's path coefficients and model fit indexes. The model fit indexes exceed their respective common acceptance levels, indicating that the displayed fitted the data well. The Chi-square is significant $\left(X_{(247)}^{2}=380.60, p<0.01\right)$, which is usually the case for large sample sizes. All but two of the statistics are within the acceptable ranges, indicating a good fit to the data. The values for GFI (.86) and AGFI (.83) are acceptably close to the standards suggested by Hu and Bentler (1999), and by Bove and Johnson (2006). Except GFI and AGFI values, other model fit indices were indicative of a good fit of the model to the data $(\mathrm{CFI}=0.94, \mathrm{NNFI}=0.93$, IFI $=0.94)$. Similarly, RMSEA value $(0.052)$ was well below of cut-off value 0.08 , and index of SRMR (0.083) was close or equal to acceptance level 0.08 .

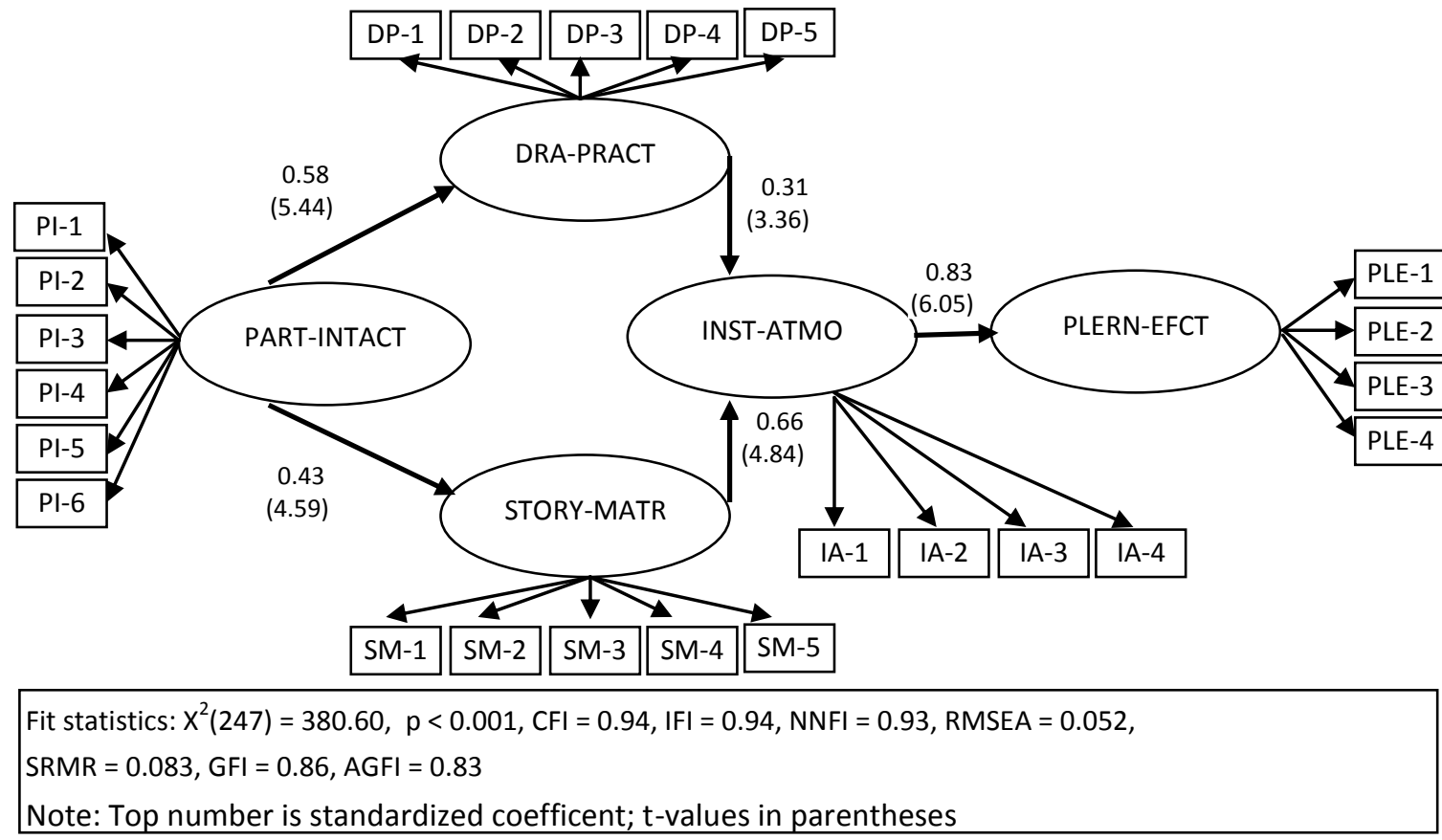

Figure 2. Structured Model of Edutainment

The five hypotheses of the study can be examined by considering the resulting structural path estimates. The structural model examines the relationships among the constructs of edutainment applications in marketing courses and learning effects. Figure 2 shows the relation between latent variables and the t-test results. All of standardized coefficients in the structural model were significant at $p<0.01$. $\mathrm{H} 1$ and $\mathrm{H} 2$ were supported by significant positive path coefficients from participation and interaction [PART-INTACT] towards story and materials [STORY-MATR] $(\beta=0.43$; $\mathrm{t}=4.59 ; p<0.01)$, and drama and practice [DRA-PRACT] $(\beta=0.58 ; \mathrm{t}=5.44 ; p<0.01)$. Similarly, $\mathrm{H} 3$ and $\mathrm{H} 4$ were also supported by significant positive path coefficients from drama and practice $(\beta=0.31$; $t=3.36 ; p<0.01)$, and story and materials $(\beta=0.66 ; t=4.84 ; p<0.01)$, toward instructor and classroom atmosphere [INST-ATMO]. Finally, as for the $\mathrm{H} 5$, there was a significant and positive relationship $(\beta=0.83 ; t=6.05 ; p<0.01)$ between instructor and classroom atmosphere and perceived learning 
effects [PLERN-EFCT]. Based on these findings, all hypotheses related to edutainment applications in marketing courses were supported.

The model shows that instructor and atmosphere ascertains mediator roles, and helps learning effects. The results of the model showed that participation and interaction in marketing courses affect drama and practice, story and material were being latent variables. Furthermore, these two latent variables affect instructor and classroom atmosphere. Finally, both instructor and the classroom atmosphere were found effective on students' recall and comprehension of the content. According to the model, instructor and classroom atmosphere has a mediator effect on learning, whereas constructs of participation and interaction, drama and practice, and story and material have an indirect effect on perceived learning. The directions of effects of relationships between all constructs were found to be positive.

\section{Discussion and Conclusion}

The main purpose of this study was developing a measurement model of edutainment application in marketing courses. This study developed a 24-item scale instrument along with three items for demographics to assess constructs related to edutainment applications. The results showed that constructs about attitudes towards edutainment applications could be conceptualized and measured as a five-dimensional construct comprising participation and interaction, learning effects, drama and practice, instructor and classroom atmosphere, and story and materials. Confirmatory factor analysis (CFA) revealed that majority of the constructs were having acceptable reliability and validity scores.

The results of the structural equation model (SEM) suggested that all developed hypotheses were accepted, indicating positive and significant relationships between variables. The relationship between constructs pointed that the effect of entertainment elements on learning is related to instructors' in-class performance. In other words, variables other than instructors and classroom atmosphere were latent and have indirect effect on mediator variables. Similarly, the relationship between participation and interaction and learning can only be established with two latent variables of drama and practice, and story and materials. These two latent variables were found to be related to instructor and classroom atmosphere, and this relationship has a mediating role over perceived learning.

The outcome of the model indicates a positive yet limited effect of edutainment over learning process. Such effect becomes more evident in classroom atmosphere of which was created by instructors. Findings of this study as well as previous studies also indicate that teaching in a way that helps gather students' attention are more appreciated by students. Evidently, use of edutainment can help lifting the students' attention and participation can be limited to marketing courses. Instead, the use edutainment can be extended to other disciplines.

From a theoretical perspective, this study examines several interesting subjects. It appears that the students' attitudes toward entertainment applications can be evaluated as a key indicator in determining learning of marketing courses. Attitudes toward edutainment in marketing courses also are a significant predictor of interaction and students participation. 
Based on the findings regarding the entertainment applications in courses of marketing and other fields of social sciences, it can be suggested that instructors at tertiary level should pay more attention to the edutainment aspects of the courses. These findings may allow university management to have a better understanding of the aspects that affect perceptions of different application in various courses.

Consequently, modern day marketing education approaches are more prone to learner-centered solutions. From this point of view, exploring the perceptions of students toward teaching and learning methods at tertiary level become a necessity for universities. Students' attitudes and perceptions on teaching and learning activities should be matched with contemporary learning theories.

How far academics should go deep into the "jungle" of using technology in classes? Will use of excessive technology one day replace instructors? Do students really like the age-old "sage on the stage" approach? Obviously there are no clear-cut and easy answers to these questions. Rather, this requires more of educational technologists' involvement to the issues of similar nature. After all, what we consider an accomplishment is to come up with a right product, with right wrapping, wouldn't it?

\section{Limitations and Recommendations}

This study has some limitations and naturally suggests possible avenues for future research. The current study focused specifically on limited number of marketing courses and university students. More comprehensive units of sample may generate more reliable results. In addition to that, this study is limited to attitudes of selected students who enrolled to selected marketing courses. In other words, the study examined the perception of participants on edutainment within the context of selected marketing courses, thus limited the participants' perceptions. For assessing the effects of edutainment applications over learning, experimental studies are needed and such concerns were not addressed within the context of this study. Future research on edutainment based on university education could be extended to include a wider span of courses, and academic fields in order to further explore the extent to which the findings are generalizable. Similarly, future research constructs can be extended to include other fields or disciplines.

\section{References}

Allred, C.R. \& Swenson, M.J. (2006). Using technology to increase student preparation for and participation in marketing courses: The Random Selector Model. Marketing Education Review, 16(1), 15-21.

Appleton-Knapp, S.L. \& Krentler, K.A. (2006). Measuring student expectations and their effects on satisfaction: The importance of managing student expectations. Journal of Marketing Education, 28(3), 254-264. 
Bagozzi, R.P. \& Yi, Y. (1988). On the evaluation of structural equations models. Journal of the Academy of Marketing Science, 16(1), 74-94.

Bird, S.A. (2005). Language learning edutainment: mixing motives in digital resources. Regional Language Centre Journal, 36(3), 311-339.

Bitner, M. J. (1992). Servicescapes: The impact of physical surroundings on customer and employees. Journal of Marketing, 56, 57-71.

Bobbitt, L.M., Inks, S.A., Kemp, K.J., \& Mayo, D.T. (2000). Integrating marketing courses to enhance team-based experiential learning. Journal of Marketing Education, 22(1), 15-24.

Bove, L.L. \&Johnson, L.W. (2006). Customer loyalty to one service worker: Should it be discouraged. International Journal of Research in Marketing, 23, 79-91.

Browne, M. W. \& Cudeck, R. (1993). Alternative ways of assessing model fit. In K. A. Bollen, \& J. S. Long (Eds.), Testing structural equation models. Beverly Hills: Sage.

Buckingham, D. \& Scanlon, M. (2002). Education, edutainment, and learning in the home, Cambridge: Open University Press, 2002.

Child, D. (1970). The Essentials of factor analysis. London: Holt, Rhinehart and Winston.

Chin, W.W. (1998), Commentary: Issues and option on structural equation modeling, MIS Quarterly, 20(1), 7-16.

Churchill, G.A. (1995). Marketing research. Fort Worth: The Dryden Press.

Churchill, G.A. (1979). A paradigm for developing better measures of marketing constructs. Journal of Marketing Research, 16(1): 64-73.

Clarke, B. (2008). Case and experiential learning methods. Marketing Education Review, 18(2), 54.

Clarke, I., Flaherty, T.B., \& Mottner, S. (2001). Student perceptions of educational technology tools. Journal of Marketing Education, 23(3), 169-77.

Cowton, C. J. (1998). The use of secondary data in business ethics research. Journal of Business Ethics, 17(4), 423-434.

Curran, J.M. \& Rosen, D.E. (2006). Student attitudes toward college courses: An examination of influences and intentions. Journal of Marketing Education, 28(2), 135-148.

Dallimore, E. J., Hertenstein, J.H., \& Platt, M.B. (2006). Nonvoluntary class participation in graduate discussion courses: Effects on grading cold calling. Journal of Management Education, 30(2), 354-377.

Egenfeldt-Nielsen, S. (2007). Third generation educational use of computer games. Journal of Educational Multimedia and Hypermedia, 16(3), 263-281.

Frontczak, N. T. and. Kelley, C. A. (2000). The editor's corner: Special issue on experiential learning in marketing education. Journal of Marketing Education, 22, 3-4.

Gefen, D., Straub, D. W., \& Boudreau, M. C. (2000). Structural equation modeling and regression: Guidelines for research practice. Communications of the AIS, 4 (7), 1-78. 
Gerbing, D. W. \& Anderson, J. C. (1988). 'An updated paradigm for scale development incorporating unidimensionality and its assessment', Journal of Marketing Research, 25(2), 186-192.

Green, M. \& McNeese, M. N. (2007). Using edutainment software to enhance online learning. International Journal on Elearning, 6(1), 5-16.

Hair, J.F., Anderson, R.L., \& Tatham, W.C. (1998). Multivariate data analysis with reading. NJ: Upper Saddle River: Prentice-Hall.

Hu, L. \& Bentler, P. M. (1999). Cutoff criteria for fit indexes in covariance structure analysis: Conventional criteria versus new alternatives. Structural Equation Modeling, 6(1), 1-55.

Jöreskog, K. G. \& Sörbom, D. (1998), Lisrel 8.20 and Prelis 2.20 for Windows, Chicago, Scientific Software.

Kim, S. S., Lee, C.K., \& Klenosky, D. B. (2003). The influence of push and pull factors at Korean national parks. Tourism Management, 24, 169-180.

Klink, R..R. and Athaide, G.A. (2004). Implementing service learning in the principles of marketing course. Journal of Marketing Education, 26(2), 145-153.

Kinney, T. (1995). Entertainment technology and tomorrow's information services. Medford, NJ: Information Today for the American Society for Information Science.

Lee, J., Graefe, A.R. \& Burns, R.C. (2007). Examining the antecedents of destination loyalty in a forest setting. Leisure Sciences, 29, 463-481.

Li, Y., Liu, Y., \& Zhao, Y. (2006). The role of market and entrepreneurship orientation and internal control in the new product development activities of Chinese firms. Industrial Marketing Management, 35, 336-347.

Longo, M. \& Mura, M. (2007). A multidimensional measure of employees' intangibles. A managerial implementation of the tool. Management Research News, 30(8), 548-569.

Meehl, P.E. (1990), Why summaries of research on psychological theories are often uninterpretable, Psychological Reports, 66, 195-244.

Moncrief, W. C. (1991). The use of sales management role play exercises. Marketing Education Review,1, 46-55.

Nunn, C. E. (1996), discussion in the college classroom, triangulating observational and survey results. The Journal of Higher Education, 67(3), 243-266.

Nunnally, J. C. (1978). Psychometric theory (2nd ed.). New York: McGraw-Hall.

Okan, Z. (2003). Edutainment: Is learning at risk? British Journal of Educational Technology, 34(3), 255-264.

Ozer, A., Kocak, A. \& Celik, O. (2006). Determinants of market orientation in accounting firms. Marketing Intelligence \& Planning, 24(6), 591-607.

Pearce, G. (2006). University student perceptions of the difference between educational drama and other types of educational experiences. Marketing Education Review, 16(2), 23-35. 
Schee, B.A.V. (2007). Setting the stage for active learning: an interactive marketing class activity. Marketing Education Review, 17(1), 63-67.

Sojka, J.Z. \& Fish, M.S.B. (2008). Brief in-class role plays: An experiential teaching tool targeted to generation y students. Marketing Education Review, 18(1), 25-31.

Solomon, M. R., Surprenant, C.F., Czepiel, J.A., \& Gutman, E.G. (1985). A role theory perspective on dyadic interactions: The service encounter. Journal of Marketing, 49, 99-111.

Soto-Acosta, P. \& o-Cerdan, A.L.M. (2008). Analyzing e-business value creation from a resourcebased perspective. International Journal of Information Management, 28, 49-60.

Stapleton, R. J. \& Murkison, G. (2001). Optimizing the fairness of student evaluations: A study of excellence, study production, learning production, and expected grades. Journal of Management Education, 25, 269-291.

Tanner, J. F. J. \& Chonko, L.B. (1992). Avoiding the guillotine effect after video-taping role plays. Marketing Education Review, 1, 37-41.

Uslay, C. (2007). Case analyses with extensive student involvement: Management versus consultants case method (MCM). Marketing Education Review, 17(1), 21-27.

Young, M.R., Klemz, B.R., \& Murphy, J. W. (2003). Enhancing learning outcomes: The effects of instructional technology, learning styles, instructional methods, and student behavior. Journal of Marketing Education, 25(2), 130-142.

Wooldridge, B.R. (2008). Golden duck awards: An interactive game to facilitate class participation. Marketing Education Review, 18(1), 15-17.

Wooldridge, B.R. (2006). The power of perception: An active/experiential learning exercise for principles of marketing. Marketing Education Review, 16(2), 5-7.

Zhang, J.J., Pennington, G.L., Connaughton, D.P., Braunstein, J.R., Ellis, M. H., Lam, E. T. C., \& Williamson, D. (2003). Understanding women's professional football game spectators: sociodemographics, game consumption, and entertainment options. Sport Marketing Quarterly, 12(4), 228-243.

Correspondence: Necip Serdar Sever, Assistant Professor , Faculty of Communication Sciences, Anadolu University, Yunus Emre Campus, 26470, Eskisehir, Turkey 